\title{
THE IMPLEMENTATION OF INDUCTIVE TEACHING AND LEARNING METHODS IN ISLAMIC EDUCATION LEARNING
}

\author{
Ali Miftakhu Rosyad \\ Fakultas Agama Islam Universitas Wiralodra \\ E-Mail:miftakhurosyad@gmail.com
}

\begin{tabular}{|c|c|c|}
\hline Received & Revised & Accepted \\
\hline 4 July 2019 & 2 Agustus 2019 & 20 Agustus 2019 \\
\hline
\end{tabular}

\begin{abstract}
The article aims to describe the essence of inductive method in Islamic education learning. The learning will run optimally if the teacher utilize the suitable approach and method.Traditional engineering instruction is deductive, beginning with theories and progressing to applications of those theories. Alternative teaching approaches are more inductive. The Islamic education learning should be utilized the inductive method. Topics are introduced by presenting specific observations, case studies or problems, and theories are taught or the students are helped to discover them only after the need to know them has been established. Factually, in modern era the Islamic education learning must be innovated for answering the globalization demand.
\end{abstract}

Keywords: inductive method, Islamic education learning, and learning innovation.

\section{Introduction}

Based on the current educational system, today the role formal education has gradually become more and more significant as it is not only for transmission of knowledge and skills but also concerned with social, religious and moral development, which in the traditional Muslim society it mainly was the parent's responsibility. For Muslim children, teaching Islamic education is emphasised in the Integrated Curriculum for Secondary School to cover general and special observance of worship and the concept of worship in Islam. The challenge of teaching is not just the acquisition of knowledge and understanding of the facts as a basis to understand the teachings of Islam. The teacher's role is not merely to transfer the facts of Islam into the minds of students, who then reiterate that knowledge in evaluations and 
examinations. Religious teaching in Islamic education and understanding of the facts by the student can impact their Islamic life and to live in the multi-cultural society. In addition, based on the recent twenty-first-century teaching and learning process, all teachers should take into account both the multi-culture and ethic environments as it will eliminate any kind of bias or misunderstanding towards others and to promote better understanding and respect among each other ${ }^{1}$.

Engineering and science are traditionally taught deductive ly. The instructor introduces a topic by lecturing on general principles, then uses the principles to derive mathematical models, shows illustrative applications of the models, gives students practice in similar derivations and applications in homework, and finally tests their ability to do the same sorts of things on exams. Little or no attention is initially paid to the question of why any of that is being done what real world phenomena can the models explain, what practical problems can they be used to solve, and why the students should care about any of it. The only motivation to learn that students get if they get any at all is suggestions that the material will be important later in the curriculum or in their careers. A well-established precept of educational psychology is that people are most strongly motivated to learn things they clearly perceive a need to know ${ }^{2}$. Simply telling students that they will need certain knowledge and skills some day is not a particularly effective motivator. A preferable alternative is inductive teaching and learning. Instead of beginning with general principles and eventually getting to applications, the instruction begins with specifics a set of observations or experimental data to interpret, a case study to analyze, or a complex real- world problem to solve. As the students attempt to analyze the data or scenario or solve the problem, they generate a need for facts, rules, procedures, and guiding principles, at which point they are either presented with the needed information or helped to discover it for themselves.

Inductive teaching and learning is an umbrella term that encompasses a range of instructional methods, including inquiry learning, problem-based learning, project-based learning, case-based teaching, discovery learning, and just-in-time teaching. These methods have many features in common, besides the fact that they all qualify as inductive. They are all learner- centered (aka studentcentered), meaning that they impose more responsibility on students for their own learning than the traditional lecture-based deductive approach does ${ }^{3}$. They are all supported by research findings that students learn by fitting new information into existing cognitive structures and are unlikely to learn if the information has few apparent connections to what they already know and believe. They can all be characterized as constructivist methods, building on the widely accepted principle that students construct their own versions of reality rather than simply absorbing versions presented by their teachers. The methods almost

\footnotetext{
${ }^{1}$ Nur Hanani Hussin and Ab Halim Tamuri, "Embedding Values in Teaching Islamic Education among Excellent Teachers," Journal for Multicultural Education 13, no. 1 (2019): 2-18.

${ }^{2}$ Mark A Albanese and Susan Mitchell, "Problem-Based Learning: A Review of Literature on Its Outcomes and Implementation Issues," ACADEMIC MEDICINE-PHILADELPHIA- 68 (1993): 52.

${ }^{3}$ Richard M Felder and Rebecca Brent, "Effective Strategies for Cooperative Learning," Journal of Cooperation \& Collaboration in College Teaching 10, no. 2 (2001): 69-75.
} 
always involve students discussing questions and solving problems in class (active learning), with much of the work in and out of class being done by students working in groups (collaborative or cooperative learning). The defining characteristics of the methods and features that most of them share are summarized in Table 1.

\section{Table 1. Features of Common Inductive Instructional Methods}

\begin{tabular}{|c|c|c|c|c|c|c|}
\hline $\begin{array}{l}\text { Method } 0 \\
\text { Feature } \\
\text { ? }\end{array}$ & 坣 & 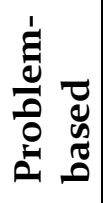 & 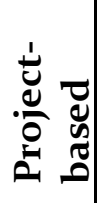 & 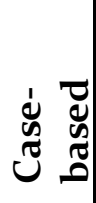 & 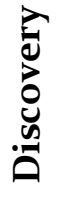 & $=$ \\
\hline Questions or problems provide context for learning & $\mathbf{1}$ & 2 & 2 & 2 & 2 & 2 \\
\hline $\begin{array}{l}\text { Complex, ill-structured, open-ended real-world } \\
\text { problems provide context for learning }\end{array}$ & 4 & $\mathbf{1}$ & 3 & 2 & 4 & 4 \\
\hline Major projects provide context for learning & 4 & 4 & $\mathbf{1}$ & 3 & 4 & 4 \\
\hline Case studies provide context for learning & 4 & 4 & 4 & $\mathbf{1}$ & 4 & 4 \\
\hline Students discover course content for themselves & 2 & 2 & 2 & 3 & 1 & 2 \\
\hline $\begin{array}{l}\text { Students complete \& submit conceptual exercises } \\
\text { electronically; instructor adjusts lessons according to } \\
\text { their responses }\end{array}$ & 4 & 4 & 4 & 4 & 4 & $\mathbf{1}$ \\
\hline Primarily self-directed learning & 4 & 3 & 3 & 3 & 2 & 4 \\
\hline Active learning & 2 & 2 & 2 & 2 & 2 & 2 \\
\hline Collaborative/cooperative (team-based) learning & 4 & 3 & 3 & 4 & 4 & 4 \\
\hline
\end{tabular}

1 - by definition, 2 -always, 3-usually, 4- possibly

There are also differences among the different inductive methods. The end product of a project-based assignment is typically a formal written and/or oral report, while the end product of a guided inquiry may simply be the answer to an interesting question, such as why an egg takes longer to boil at a ski resort than at the beach and how frost can form on a night when the temperature does not drop below freezing. Case-based instruction and problem-based learning involve extensive analyses of real or hypothetical scenarios while just in time teaching may simply call on students to answer questions about readings prior to hearing about the content of the readings in lectures. However, the similarities trump the differences, and when variations in how the methods are implemented are taken into account many of the differences disappear altogether ${ }^{4}$.

Although we just claimed that inductive methods are essentially variations on a theme, they do not appear that way in the literature. Each method has its own history, research base, guidebooks, proponents, and detractors, and a great deal of confusion exists regarding what the methods are and how they are

\footnotetext{
${ }^{4}$ Richard R Hake, "Interactive-Engagement versus Traditional Methods: A Six-Thousand-Student Survey of Mechanics Test Data for Introductory Physics Courses," American Journal of Physics 66, no. 1 (1998): 64-74.
} 
interrelated. Our objective in this paper is to summarize the definitions, foundations, similarities, and differences among inductive learning methods and to review the existing research evidence regarding their effectiveness.

In the Islamic religious education, there are three main material, namely faith, worship and morality . The three subject matter is then elaborated into 7 aspects of the scope of Islamic learning which consist of: Qur'an and Hadith Faith, Morals, Fiqh, Islamic History and Culture. Integration of de-radicalization into Islamic religious learning can be done by linking de-radicalization with standard of competence and basic competencies to each of the scope of learning. Books as learning material are one of the focuss in de-radicalization implementation. Through review or teaching material that is in the textbook, educators and students gain an understanding of something that can provide reinforcement of the understanding that they already had. In order to achieve optimal results, the integration of course must be supported by strategies, approaches, methods and learning techniques that are in accordance with Islamic religious subject and the conditions of students 5 .

Before we begin our review, we will attempt to clarify two points of confusion that commonly arise in discussions of inductive methods.

\section{Literature Review}

\section{The Essence of Inductive Method}

Inductive learning method is the learning method which the teacher begin the material learning from factual condition to some theories. In practice, neither teaching nor learning is ever purely inductive or deductive. Like the scientific method, learning invariably involves movement in both directions, with the student using new observations to infer rules and theories (induction) and then testing the theories by using them to deduce consequences and applications that can be verified experimentally (deduction). Good teaching helps students learn to do both ${ }^{6}$. When we speak of inductive methods, we therefore do not mean total avoidance of lecturing and complete reliance on self- discovery, but simply teaching in which induction precedes deduction. Except in the most extreme forms of discovery learning (which we do not advocate for undergraduate instruction), the instructor still has important roles to play in facilitating learning guiding, encouraging, clarifying, mediating, and sometimes even lecturing. We agree with Bransford: "There are times, usually after people have first grappled with issues on their own, that 'teaching by telling' can work extremely well"?

\footnotetext{
${ }^{5}$ Edhy Rustan, Nurul Hanifah, and Bulu' Kanro, "De-Radicalization in the Implementation of Islamic Education Curriculum in SMA Masamba South Sulawesi.," Dinamika IImu 18, no. 2 (2018): 271-83.

${ }^{6}$ Washington National Academy of Sciences-National Research Council DC., How People Learn: Brain, Mind, Experience, and School (ERIC Clearinghouse, 1999).

${ }^{7}$ Barbara Oakley et al., "Turning Student Groups into Effective Teams," Journal of Student Centered Learning 2, no. 1 (2004): 9-34.
} 
A common point of semantic confusion associated with inductive methods has to do with the distinction between teaching and learning. Thus, for example, one hears about problem-based learning but just- in-time teaching, and both inquiry learning and inquiry-based teaching are commonly encountered in the literature. There is of course a difference between learning (what students do) and teaching (what teachers do $)^{8}$, but in this paper we will never examine one without explicitly or implicitly considering the other. The reader should therefore understand that when we refer to "inductive learning" or to an inductive instructional method with either teaching or learning in its name, we are talking about both strategies that an instructor might use (teaching) and experiences the students might subsequently undergo (learning).

\section{Constructivism Teories}

According to the model of education that has dominated higher education for centuries (positivism), absolute knowledge ("objective reality") exists independently of human perception. The teacher's job is to transmit this knowledge to the students lecturing being the natural method for doing so and the students' job is to absorb it $^{9}$. An alternative model, constructivism, holds that whether or not there is an objective reality (different constructivist theories take opposing views on that issue), individuals actively construct and reconstruct their own reality in an effort to make sense of their experience. New information is filtered through mental structures (schemata) that incorporate the student's prior knowledge, beliefs, preconceptions and misconceptions, prejudices, and fears. If the new information is consistent with those structures it may be integrated into them, but if it is contradictory, it may be memorized for the exam but is unlikely to be truly incorporated into the individual's belief system which is to say, it will not be learned ${ }^{10}$.

Constructivism has its roots in the $18^{\text {th }}$-century philosophies of Immanuel Kant and Giambattista Vico, although some have traced it as far back as the $4^{\text {th }}$ $6^{\text {th }}$ century B.C. in the works of Lao Tzu, Buddha, and Heraclitus. The constructivist view of learning is reflected in the developmental theories of Piaget $^{11}$, Dewey ${ }^{12}$, Bruner ${ }^{13}$, and Vygotsky $^{14}$, among others. In cognitive constructivism, which originated primarily in the work of Piaget, an individual's reactions to experiences lead to (or fail to lead to) learning. In social

\footnotetext{
${ }^{8}$ Paul Ramsden, Learning to Teach in Higher Education (Routledge, 2003).

${ }^{9}$ David A Kolb, Experiential Learning: Experience as the Source of Learning and Development (FT press, 2014).

${ }^{10}$ Patrick T Terenzini et al., “Collaborative Learning vs. Lecture/Discussion: Students' Reported Learning Gains," Journal of Engineering Education 90, no. 1 (2001): 123-30.

${ }^{11}$ Jean Piaget, The Essential Piaget, vol. 5076 (Basic Books (AZ), 1977).

12 John Dewey, “How We Think. Mineola," New York: Courier Dover, 1997.

13 Jerome S Bruner, "The Act of Discovery," 1961.

14 Jane E Knox and Carol Stevens, "Vygotsky and Soviet Russian Defectology," in The Collected Works of LS Vygotsky (Springer, 1993), 1-25.
} 
constructivism, whose principal proponent is Vygotsky, language and interactions with others family, peers, teachers play a primary role in the construction of meaning from experience. Meaning is not simply constructed, it is coconstructed.

Proponents of constructivism ${ }^{15}$ offer variations of the following principles for effective instruction:

1) Instruction should begin with content and experiences likely to be familiar to the students, so they can make connections to their existing knowledge structures. New material should be presented in the context of its intended real-world applications and its relations hip to other areas of knowledge, rather than being taught abstractly and out of context.

2) Material should not be presented in a manner that requires students to alter their cognitive models abruptly and drastically. In Vygotsky's terminology, the students should not be forced outside their "zone of proximal development," the region between what they are capable of doing independently and what they have the potential to do under adult guidance or in collaboration with more capable peers [6]. They should also be directed to continually revisit critical concepts, improving their cognitive models with each visit. As Bruner ${ }^{16}$ puts it, instruction should be "spirally organized."

3) Instruction should require students to fill in gaps and extrapolate material presented by the instructor. The goal should be to wean the students away from dependence on instructors as primary sources of required information, helping them to become self- learners.

4) Instruction should involve students working together in small groups. This attribute whic $\mathrm{h}$ is considered desirable in all forms of constructivism and essential in social constructivism - supports the use of collaborative and cooperative learning.

The traditional lecture-based teaching approach is incompatible with all of these principles. If the constructivist model of learning is accepted and compelling research evidence supports it then to be effective instruction must set up experiences that induce students to construct knowledge for themselves, when necessary adjusting or rejecting their prior beliefs and misconceptions in light of the evidence provided by the experiences. This description might serve as a definition of inductive learning.

\footnotetext{
15 John Biggs, "Enhancing Teaching through Constructive Alignment," Higher Education 32, no. 3 (1996): 347-64.

${ }^{16}$ Bruner, "The Act of Discovery."
} 


\section{Intellectual Development and Approaches to Learning}

Most college students undergo a developmental progression from a belief in the certainty of knowledge and the omniscience of authorities to an acknowledgment of the uncertainty and contextual nature of knowledge ${ }^{17}$, acceptance of personal responsibility for determining truth, inclination and ability to gather supporting evidence for judgments, and openness to change if new evidence is forthcoming ${ }^{18}$. At the highest developmental level normally seen in college students (termed "contextual relativism" by Perry, individuals display thinking patterns resembling those of expert scientists and engineers. A goal of science and engineering instruction should be to advance students to that level by the time they graduate.

In their courses, students may be inclined to approach learning in one of three ways ${ }^{19}$. Some take a surface approach, relying on rote memorization and mechanical formula substitution and making little or no effort to understand the material being taught. Others may adopt a deep approach, probing and questioning and exploring the limits of applicability of new material. Still others use a strategic approach, doing whatever is necessary to get the highest grade they can, taking a surface approach if that suffices and a deep approach when necessary. Another goal of instruction should be to induce students to adopt a deep approach to subjects that are important for their professional or personal development.

Felder \& Brent observe that the characteristics of high levels of intellectual development and of a deep approach to learning are essentially the same. Both contextual relativism and a deep approach involve taking responsibility for one's own learning, questioning authorities rather than accepting their statements at face value, and attempting to understand new knowledge in the context of prior knowledge and experience. It is reasonable to assume that instructional conditions that induce students to adopt a deep approach should also promote intellectual growth ${ }^{20}$.

Several conditions of instruction have been shown to promote a deep approach, including interest in and background knowledge of the subject, use of teaching methods that foster active and long-term engagement with learning tasks, and assessment that emphasizes conceptual understanding as opposed to recall or the application of routine procedural knowledge ${ }^{21}$. Well implemented inductive teaching methods serve all of these functions. Authentic problems and case studies can motivate students by helping to make the subject matter relevant, and they also tend to keep the students interested and actively engaged in their learning tasks. Having to analyze complex situations also promotes the students' adoption of a deep approach to learning, as rote

\footnotetext{
${ }^{17}$ Terenzini et al., "Collaborative Learning vs. Lecture/Discussion: Students' Reported Learning Gains."

${ }^{18}$ William G Perry Jr, Forms of Intellectual and Ethical Development in the College Years: A Scheme. JosseyBass Higher and Adult Education Series. (ERIC, 1999).

${ }^{19}$ Felder and Brent, "Effective Strategies for Cooperative Learning."

${ }^{20}$ Felder and Brent.

${ }^{21}$ Felder and Brent.
} 
memorization and simple algorithmic substitution are clearly inadequate strategies for dealing with such situations. Moreover, open-ended problems that do not have unique well- defined solutions pose serious challenges to students' low-level beliefs in the certainty of knowledge and the role of instructors as providers of knowledge. Such challenges serve as precursors to intellectual growth $^{22}$.

\section{Learning Cycle-Based Instruction}

Several well-known instructional models involve learning cycles, wherein students work through sequences of activities that involve complementary thinking and problem-solving approaches. In most of these cycles, the different activities are designed to appeal to different learning style preferences (concrete and abstract, active and reflective, etc. $)^{23}$. When instructors teach around the cycle in this manner, all students are taught partly in a manner they prefer, which leads to an increased comfort level and willingness to learn, and partly in a less preferred manner, which provides practice and feedback in ways of thinking they might be inclined to avoid but which they will have to use to be fully effective professionals. Teaching around the best known of such cycles that associated with Kolb's experiential learning model $^{24}$ involves (1) introducing a problem and providing motivation for solving it by relating it to students' interests and experience (the focal question is why?); (2) presenting pertinent facts, experimental observations, principles and theories, problem-solving methods, etc., and opportunities for the students to reflect on them (what?); (3) providing guided hands-on practice in the methods and types of thinking the lessons are intended to teach (how?); and (4) allowing and encouraging exploration of consequences and applications of the newly learned material (what if?).

A learning cycle developed at the Vanderbilt University Learning Technology Center is the STAR Legacy module ${ }^{25}$, which consists of the following steps:

1) Students are presented with a challenge (problem, scenario, case, news event, or common misconception presenting the targeted content in a realistic context) that establishes a need to know the content and master the skills included in the learning objectives for the module.

2) The students then formulate their initial thoughts, reflecting on what they already know and think about the context of the challenge and generating ideas about how they might address the challenge.

3) Perspectives and resources are next provided. Perspectives are statements by

\footnotetext{
${ }^{22}$ Perry Jr, Forms of Intellectual and Ethical Development in the College Years: A Scheme. Jossey-Bass Higher and Adult Education Series.

${ }^{23}$ Ramsden, Learning to Teach in Higher Education.

${ }^{24}$ Richard M Felder, "Matters of Style," ASEE Prism 6, no. 4 (1996): 18-23.

${ }^{25}$ Kolb, Experiential Learning: Experience as the Source of Learning and Development.
} 
experts that offer insights into various dimensions of the challenge without providing a direct solution to it, and resources may include lectures, reading materials, videos, simulations, homework problems, links to websites, and other materials relevant to the challenge.

4) Assessment activities are then carried out, in which the students apply what they know and identify what they still need to learn to address the challenge. The activities may include engaging in self-assessments and discussions, completing homework assignments, writing essays or reports, and taking online quizzes or exams. Multiple iterations between Steps 3 and 4 would normally be required to fully meet the challenge.

5) In the final wrap-up, an expert may present a model solution to the challenge, or the students may present a report and/or complete an examination showing that they have met the challenge and demonstrating their mastery of the knowledge and skills specified in the learning objectives.

The Star legacy module is a clear exemplar of an inductive approach to teaching and learning. Depending on the nature and scope of the challenge, instruction based on such a module wo uld qualify as inquiry learning, project-based learning, or problem-based learning. Similarly, learning cycles based on learning styles that begin with the presentation of a realistic problem or challenge of some sort are inductive. Instruction based on learning cycles is consistent with accepted principles of cognitive science ${ }^{26}$ and its effectiveness has been repeatedly demonstrated empirically ${ }^{27}$.

In summary, inductive approaches to teaching and learning have much in their favor. They are supported by the best research on learning currently available, compatible with the currently most widely accepted theories of learning, and promotive of the problem-solving skills and attitudes to learning that most instructors would say they desire for their students. Following a brief section on assessment, we will examine the individual inductive methods what they are, what they have in common and how they differ, and what is known about how well they succeed in achieving desired educational outcomes.

\section{Assessment and Evaluation of Inductive Methods}

Rigorous comparisons of inductive methods with traditional expository methods are not easy to design, for several reasons ${ }^{28}$.

1) There are many varieties of inductive approaches, each of which can be implemented in many ways with greater or lesser instructor involvement, with

\footnotetext{
${ }^{26}$ John D Bransford, Ann L Brown, and Rodney R Cocking, How People Learn, vol. 11 (Washington, DC: National academy press, 2000).

${ }^{27}$ Swati Sharma, “Acceptance and Embracing New Teaching Technologies in Management Education," EXCEL International Journal of Multidisciplinary Management Studies 4, no. 11 (2014): 4-11.

${ }^{28}$ Felder and Brent, "Effective Strategies for Cooperative Learning."
} 
or without formal facilitation of teamwork, with most of the work being done in or out of class, and so on. Two articles may claim to be studies of, say, problem-based learning, but they could involve dramatically different forms of instruction and may well produce different learning outcomes.

2) Instructors may have varying degrees of experience and skill with whichever method they adopt. Two different instructors using the same method in the same class could get different results.

3) Student populations also vary considerably, among other ways in distributions of gender and ethnicity, age, experience, motivation to learn, learning styles, and levels of intellectual development ${ }^{29}$. The same instructor could use the same method in two different classes and get different outcomes.

4) The conclusions drawn from a study may depend strongly on the learning outcome investigated acquisition of factual knowledge, development of a problem-solving or interpersonal skill, retention in a curriculum, selfconfidence level, attitude, or any combination of these. An inductive method may be superior with respect to one outcome and inferior with respect to another. (We will shortly see an example of this phenomenon in the case of problem-based learning, which has frequent ly been found to lead to superior high- level skills and attitudes but inferior short-term acquisition of factual knowledge.) Moreover, reliable and valid assessments of high- level skills such as critical or creative thinking or attributes such as lifelong learning skills are difficult to obtain, and two studies that use different assessment methods could arrive at different conclusions.

5) Finally, as Prince ${ }^{30}$ points out, implementations of inductive approaches such as problem- based learning normally involve active and collaborative learning methods, both of which are known to have positive effects on many learning outcomes. If an inductive method is found to have a positive effect, sorting out how much of it can be attributed to the method itself and how much to other methods imbedded in it can be a formidable challenge.

Considering these difficulties, it is not surprising that published studies report both positive and negative outcomes for inductive learning relative to conventional instruction. Given the difficulty (if not impossibility) of carrying out a clean and conclusive comparative study, the best we can do is to look at results from a number of studies with different instructors, implementations, learning outcomes, and student populations, to see if any robust generalizations can be inferred. The sections that follow summarize results of such meta-analyses.

\footnotetext{
${ }^{29}$ Felder and Brent.

${ }^{30}$ Felder and Brent.
} 


\section{Getting Started With Inductive Teaching and Learning}

Once instructors are persuaded that inductive teaching methods are worth attempting, they face the question of which method to use. The answer, like the answer to all real questions, begins with "it depends": specifically, it depends on the instructor's learning objectives, the instructor's and the students' prior experience with learner-centered teaching methods, the instructor's confidence in his or her content knowledge and teaching skill, and the availability of local expertise and support for each of the various methods.

Before teaching a topic or series of lessons using any inductive method, the instructor should write learning objectives that define what the student should be able to do (explain, calculate, derive, design, model, critique,...) when the instruction has been concluded. The objectives should guide the choice of focus problems, learning activities, and assessment methods. Mager ${ }^{31}$ and Gronlund ${ }^{32}$ grprovide guidance on how to write effective learning objectives, and Felder and Brent $^{33}$ discuss writing objectives to address Outcomes $3 \mathrm{a}-3 \mathrm{k}$ of the ABET Engineering Criteria.

Once learning objectives have been defined, a suitable inductive instructional method may be identified. We propose the following guidelines for making the choice:

1) Inquiry learning. Inquiry is the simplest of the inductive approaches and might be the best one for inexperienced or previously traditional instructors to begin with. It requires designing instruction so that as much learning as possible takes place in the context of answering questions and solving problems. As the students gain more experience with this approach, the instructor may increase the scope and difficulty of the focus questions, use more open-ended and ill-structured problems and simultaneously decrease the amount of explicit guidance provided.

2) Problem-based learning. Problem-based learning is the most complex and difficult to implement of the methods reviewed in this paper. It calls for a complex, open-ended, authentic problem whose solution requires knowledge and skills specified in the learning objectives. Such problems take time to create. PBL also requires considerable teaching skill for instructors to deal with unfamiliar technical questions and problems, student resistance and possibly hostility toward PBL, and the array of interpersonal problems that frequently arise when students work in teams. Full- fledged PBL is therefore best undertaken by experienced instructors with solid expertise in the subject matter of the course and two or more semesters of experience with cooperative learning in a more conventional instructional environment.

\footnotetext{
${ }^{31}$ Hake, "Interactive-Engagement versus Traditional Methods: A Six-Thousand-Student Survey of Mechanics Test Data for Introductory Physics Courses."

${ }^{32} \mathrm{~N}$ Gronlund, "How to Write and Use Instructional Objectives Columbus," Ohio: Merrill, 2000.

${ }^{33}$ Felder and Brent, "Effective Strategies for Cooperative Learning."
} 
Smith et al. ${ }^{34}$ offer suggestions for implementing cooperative learning, and Felder and Brent $t^{35}$ and Oakley et a ${ }^{36}$. suggest strategies for overcoming student resistance to learner-centered instructional methods and helping student groups become effective teams. Despite the challenges, PBL is a natural environment in which to develop students' professional skills such as problemsolving, team work and self-directed or lifelong learning, and it provides an excellent format to integrate material from across the curriculum. Instructors wishing to focus specifically on these learning outcomes should consider adopting PBL.

3) Project-based learning and hybrid problem/project-based approaches. Projectbased learning is well suited to the capstone design course in engineering and to laboratory courses that are more than collections of cookbook experiments, and it may also be used in other courses that deal with process or product design and development. Like the focus problems in problembased learning, projects should be authentic and should address the instructor's learning objectives; moreover, if students work in teams, the instructor should observe the principles of cooperative learning including holding all team members individually accountable for the entire project content and facilitating their acquisition of teamwork skills ${ }^{37}$. As instructors and students gain experie nce with project-based learning, the projects may be made more open-ended with less guidance being provided on how to complete them. In other words, they may be increasingly structured as problem-based learning exercises.

4) Case-based teaching. Cases are effective ly used when learning objectives include decision- making in complex authentic situations. With appropriate selection, case-based teaching can also provide an excellent environment in which to address specific ABET mandated outcomes such acquiring an understanding professional and ethical responsibility, knowledge of contemporary issues or the ability to understand engineering solutions in a global and societal context. Scenarios suitable for cases might involve diagnosing technic al problems and formulating solution strategies, making business management decisions taking into account technical, economic, and possibly social and psychological considerations, and confronting ethical dilemmas. Formulating good cases can be a difficult and time-consuming task; before trying to do it, instructors should first check the libraries of cases in science and engineering cited in Section VII to see if an existing case addresses their learningobjectives.

5) Just-in-time teaching. JiTT is a natural method to use when (1) it is important to the instructor that the students keep up with readings and assignments on a day-by-day basis, and (2) course management software is available and

\footnotetext{
${ }^{34}$ Karl A Smith et al., "Pedagogies of Engagement: Classroom-based Practices," Journal of Engineering Education 94, no. 1 (2005): 87-101.

${ }^{35}$ Felder and Brent, "Effective Strategies for Cooperative Learning."

${ }^{36}$ Oakley et al., "Turning Student Groups into Effective Teams."

${ }^{37}$ Hussin and Tamuri, "Embedding Values in Teaching Islamic Education among Excellent Teachers."
} 
convenient to use for administering on- line assignments and assessing the students' responses. Instructors who plan to use the method should have solid expertise in the course content and the flexibility needed to modify their lectures on short notice after examining students' responses to the preliminary exercises. Also, a significant expenditure of time and effort is sure to be required if the preliminary Web-based exercises and Java applets must all be developed from scratch. Before undertaking this task, instructors should see if materials can be obtained from colleagues at their institution or elsewhere who have used JiTT for the same course.

We do not recommend using the pure form of discovery learning in which students work with little or no guidance from instructors in undergraduate engineering curricula.

Once the decision about adoption of a method is made, the instructor should refer to texts, articles, and Web-based resources on the chosen method and take full advantage of experienced colleagues and teaching center consultants who can offer tips on implementing it and dealing with problems that arise with its use.

\section{The Using Inductive Method in Islamic education}

Islamic religious learning is one of the compulasary subjects in curriculum. Religious subject aims to enhance noble character and spiritual values for students. Islamic Religious Education is a continous process of planting Islamic education in which there is reciprocal relationship between educators and students aimed at the formation of good moral values ${ }^{38}$.

Curriculum 2013 is implemented to develop the character of students, shown through vertical and horizontal integration between subjects 31. Therefore, Curriculum 2013 is expected to improve students' competitiveness in responding to global issues. In curriculum 2013, teachers need fair good understanding about concept and learning process with various forms of activity to participate in principles and curriculum development ${ }^{39}$.

The implementation of curriculum 2013, especially in the study of Islam, was still experiencing obstacles in the field. Those obstacle such as the unavailability of handbooks for students, so students must be more active in looking for subject matter on the internet without an ideological filter. In addition, the main emphasizes of Islamic Religious Education on the aspects of graduate aspect in learning, character formation of students, and scientific approach.

Aspect of graduate competence in learning Islamic Religious Education emphasized affective aspects or attitudes. The results of the interview indicates that the teachers conduct affective assesstment or attitudes in order to make the

\footnotetext{
${ }^{38}$ Murray, P. (1993). Curriculum Development and Design (2nd ed.). Australia: Media Group.

${ }^{39}$ Rustan, Hanifah, and Kanro, "De-Radicalization in the Implementation of Islamic Education Curriculum in SMA Masamba South Sulawesi."
} 
students as the nations' sucessors who have noble character, can behave in line with Prophet Muhammad teachings. Character development that was very relevant to the learning of Islam was religious character, tolerance, democarcy and love-peace which was needed to be planted on students.

There were topics that had potential to contain radical elements such as material which elaborated faith in God, tolerance, jihad, brotherhood, interpretation of the Qur'an and Hadith, and wars in the history of Islamic culture. For example in basic competencies "Understanding and analyzing Q.S alHujurât (49): 10 and 12." could be potentially radical if the reformist movement of Islam in the world", potentially radical because of islamic reformerd due to the division of Muslim into several groups. Basic Competence "Understanding the concept of Jihad in Islam", was potentially radical if the concept of Jihad was considered a physical war or war using weapons to fight the enemies of Allah and enemies of Islam. Basic Competence "Accustomed to dressing in accordance with Islamic Law for Muslim women", potentially radical if you consider the clothes that used most appropriate, other Muslim clothing was considered not in line with Islamic law.

Based on the result of the interview, information was obtained that efforts to shape the character of students need to involve parents, teachers, and the community enviroment. Character formation was carried out in a process and continues manner, by orienting experiences that had been received from the environment, especially the familiy, then subsequently developed in school. Rismala's expression as teacher of Islamic Education that, learning had referred to the development and ability of students to understand. Based on the results of the interview, information was obtained that, efforts to shape the character of students need to involve parents, teachers, and the community environment. Character formation was carried out in a process and continuous manner, by orienting experiences that had been received from the environment, especially the family, and then subsequently developed in school. Rismala's expression as a teacher of Islamic Education that, learning had referred to the development and ability of students to understand, appreciate, and practice Islamic values and harmonize the value of faith according to the competence of attitudes, their authority on science and technology. Islamic learning was done through soft approach with integrated to scientific approach. That approach was implemented by preventing violence through the delivery of fact-based or real leraning material that was acceptable with reason and logic. The purpose was complied as simple as possible in interesting classess, based on concepts and theories that could be responsible for, motivated, and inspired students to be able to think critically, be able to appreciate differences, and develop rational and objective

thinking. 


\section{Conclusion}

The traditional approach in teaching and learning practice was deductive, beginning with the presentation of basic principles in lectures and proceeding to the repetition and application of the lecture content by the students. The teaching methods discussed in this paper inquiry learning, problem-based learning, project-based learning, case-based teaching, discovery learning, and just- in-time teaching instead proceed inductively, beginning with observations to be interpreted, questions to be answered, problems to be solved, or case studies to be analyzed. The content knowledge, methods, and skills that the course is designed to teach are acquired by the students, with varying degrees of instructor guidance, in the context of those exercises. If and when instructors present information, they do so only once the need for that information to complete the exercises has been established.

Islamic religious education in curriculum 2013 could foster the character of students who were religious, tolerance, democratic and loving-peace. There was a need to do prevention of radicalism in high school through the integration of Islamic religious education with the concept of de-radicalization of religion in two ways, namely introducing and instilling. Steps to introduce religious teachings as a whole, provide an understanding of Islam and nationalism in daily practice, so that it became a religious and democratic Islam. Steps to instill moderate religious values through religious teachings based on the command of Allah SWT, imitate the struggle of Prophet Muhammad, and form the character of tolerance and loving-peace.

Instructors who set out to implement an inductive method should therefore first familiarize themselves with best practices such as providing adequate scaffolding extensive support and guidance when students are first introduced to the method, followed by gradual withdrawal of the support as the students gain more experience and confidence in its use. Instructors should also anticipate some student resistance to inductive learning and should be aware of effective strategies for defusing it.

\section{REFERENCES}

Ainiyah, N. (2013). Pembentukan Karakter Melalui Pendidikan Agama Islam. Al-Ulum, 13(1), 25-38. https://doi.org/1412-0534

Murray, P. (1993). Curriculum Development and Design (2nd ed.). Australia: Media Group.

Albanese, Mark A, and Susan Mitchell. "Problem-Based Learning: A Review of Literature on Its Outcomes and Implementation Issues." ACADEMIC MEDICINE-PHILADELPHIA- 68 (1993): 52.

Biggs, John. "Enhancing Teaching through Constructive Alignment." Higher Education 32, no. 3 (1996): 347-64.

Bransford, John D, Ann L Brown, and Rodney R Cocking. How People Learn. Vol. 11. Washington, DC: National academy press, 2000. 
Bruner, Jerome S. "The Act of Discovery," 1961.

Dewey, John. “How We Think. Mineola.” New York: Courier Dover, 1997.

Felder, Richard M. "Matters of Style." ASEE Prism 6, no. 4 (1996): 18-23.

Felder, Richard M, and Rebecca Brent. "Effective Strategies for Cooperative Learning." Journal of Cooperation E Collaboration in College Teaching 10, no. 2 (2001): 69-75.

Gronlund, N. "How to Write and Use Instructional Objectives Columbus." Ohio: Merrill, 2000.

Hake, Richard R. "Interactive-Engagement versus Traditional Methods: A SixThousand-Student Survey of Mechanics Test Data for Introductory Physics Courses." American Journal of Physics 66, no. 1 (1998): 64-74.

Hussin, Nur Hanani, and Ab Halim Tamuri. "Embedding Values in Teaching Islamic Education among Excellent Teachers." Journal for Multicultural Education 13, no. 1 (2019): 2-18.

Knox, Jane E, and Carol Stevens. "Vygotsky and Soviet Russian Defectology." In The Collected Works of LS Vygotsky, 1-25. Springer, 1993.

Kolb, David A. Experiential Learning: Experience as the Source of Learning and Development. FT press, 2014.

National Academy of Sciences-National Research Council DC., Washington. How People Learn: Brain, Mind, Experience, and School. ERIC Clearinghouse, 1999.

Oakley, Barbara, Richard M Felder, Rebecca Brent, and Imad Elhajj. "Turning Student Groups into Effective Teams." Journal of Student Centered Learning 2, no. 1 (2004): 9-34.

Perry Jr, William G. Forms of Intellectual and Ethical Development in the College Years: A Scheme. Jossey-Bass Higher and Adult Education Series. ERIC, 1999.

Piaget, Jean. The Essential Piaget. Vol. 5076. Basic Books (AZ), 1977.

Ramsden, Paul. Learning to Teach in Higher Education. Routledge, 2003.

Rustan, Edhy, Nurul Hanifah, and Bulu' Kanro. "De-Radicalization in the Implementation of Islamic Education Curriculum in SMA Masamba South Sulawesi." Dinamika Ilmu 18, no. 2 (2018): 271-83.

Sharma, Swati. "Acceptance and Embracing New Teaching Technologies in Management Education." EXCEL International Journal of Multidisciplinary Management Studies 4, no. 11 (2014): 4-11.

Smith, Karl A, Sheri D Sheppard, David W Johnson, and Roger T Johnson. "Pedagogies of Engagement: Classroom-based Practices." Journal of Engineering Education 94, no. 1 (2005): 87-101.

Terenzini, Patrick T, Alberto F Cabrera, Carol L Colbeck, John M Parente, and Stefani A Bjorklund. “Collaborative Learning vs. Lecture/Discussion: Students' Reported Learning Gains.” Journal of Engineering Education 90, no. 1 (2001): 12330. 